\title{
Kejadian Anemia Pada Remaja Putri di SMP Budi Mulia Kabupaten Karawang Tahun 2018
}

\author{
Ida Farida Handayani*, Ugi Sugiarsih \\ Prodi Kebidanan Karawang Poltekkes Kemenkes Bandung, Indonesia \\ *Corresponding author: ida.ifhe@gmail.com
}

\begin{abstract}
Background: The prevalence of anemia in teenage girls is currently still extravagantly, ranging from 40-88\%, and in Indonesia, $21.7 \%$ of teenage girls are prone to anemia because they lose a lot of blood during menstruation. Teenager girls with anemia are at risk of developing anemia during pregnancy. This will have a negative impact on the growth and development of the fetus in the womb and can cause complications in pregnancy and childbirth and even cause the death of mother and child. Purposes: This study aims to determine the relationship between the determinants of the incidence of anemia in adolescent girls at Budi Mulia Karawang Junior High School in 2018. Methods: The research design used was crosssectional. The population in this study were all students of SMP Budi Mulia, with a total sample of 67 respondents. The sampling technique was simple random sampling. The data were analyzed by a chi-square statistical test. Result: The results showed that the incidence of anemia in students of SMP Budi Mulia was 38.8\%, nutritional status, dietary pattern, Fe consumption, and knowledge did not have a significant correlation with the incidence of anemia in teenager girls with a value of $p 0.005$, to wit nutritional status $(p=0.281)$, eating patterns $(p=0.728)$, consumption of fe $(p=0.730)$ and knowledge $(p=0.728)$. Conclusion: the determinant factors did not have a significant correlation with the incidence of anemia in adolescent girls.
\end{abstract}

Keywords: anemia, determinant factors, teenager girls

\begin{abstract}
ABSTRAK
Latar Belakang: Prevalensi anemia pada remaja putri saat ini masih tinggi berkisar $40-88 \%$, dan di Indonesia $21,7 \%$. Kehilangan darah saat menstruasi menyebabkan remaja putri rentan mengalami anemia, yang berisiko mengalami anemia saat hamil. Anemia dalam kehamilan mempunyai dampak negatif terhadap pertumbuhan dan perkembangan janin dalam kandungan serta berpotensi menimbulkan komplikasi kehamilan dan persalinan, bahkan menyebabkan kematian ibu dan anak. Tujuan: tujuan penelitian ingin mengetahui hubungan faktor determinan kejadian anemia pada remaja putri SMP Budi Mulia Karawang tahun 2018. Metode: desain penelitian yang digunakan yaitu cross sectional. Populasi pada penelitian adalah seluruh siswi SMP Budi Mulia, total sampel sebanyak 67 responden. Teknik pengambilan sampel secara simple random sampling, data dianalisa dengan uji statistik chi square. Hasil: hasil penelitian menunjukkan kejadian anemia pada siswi SMP Budi Mulia sebanyak 38,8 \%, status gizi, pola makan, konsumsi Fe, dan pengetahuan tidak memiliki hubungan yang bermakna dengan kejadian anemia pada remaja putri dengan nilai $p \geq 0,005$ yaitu status gizi $(\mathrm{p}=0,281)$, pola makan $(\mathrm{p}=0,728)$, konsumsi fe $(\mathrm{p}=0,730)$ dan pengetahuan
\end{abstract}


( $\mathrm{p}=0,728)$. Simpulan: faktor determinan tidak memiliki hubungan yang bermakna dengan kejadian anemia pada remaja putri.

Kata kunci: anemia, faktor determinan, remaja putri

\section{PENDAHULUAN}

Penduduk dunia 30\% menderita anemia, terutama di negara berkembang. Penderita anemia banyak terjadi dikalangan remaja dan ibu hamil. Anemia pada remaja putri sampai saat ini masih cukup tinggi, menurut World Health Organization tahun 2013, prevalensi anemia dunia berkisar $40-88 \%$ (1). Menurut data hasil Riskesdas tahun 2013, prevalensi anemia di Indonesia yaitu $21,7 \%$ dengan sebaran umur 5-14 tahun $24,6 \%$, umur 15-24 tahun 18,4\%. Data Survey Kesehatan Rumah Tangga (SKRT) tahun 2012 dilaporkan prevalensi anemia pada remaja putri 10-18 tahun sebesar $57,1 \%$. Remaja putri (Remantri) paling berisiko terkena anemia (1).

Kerentanan anemia pada remaja putri terjadi karena proses kehilangan darah saat menstruasi. Rematri yang menderita anemia berisiko mengalami anemia juga saat hamil, yang berdampak terhadap pertumbuhan dan perkembangan janin dalam kandungan serta berpotensi menimbulkan komplikasi kehamilan dan persalinan, bahkan menyebabkan kematian ibu dan anak. Angka Kematian Ibu (AKI) menurut Survey Penduduk Antar Sensus (SUPAS) 2015 sebesar 305 per 100.000 kelahiran hidup dan penyebab kematian ibu adalah pre eklampsia dan eklampsia $(32,4 \%)$ dan perdarahan pada persalinan (20,3\%) (1). Dampak anemia pada remaja dapat menyebabkan keterlambatan pertumbuhan fisik, gangguan perilaku serta emosional. Hal ini mempengaruhi proses pertumbuhan dan perkembangan sel otak sehingga dapat menimbulkan daya tahan tubuh menurun, mudah lemas, lapar, konsentrasi belajar terganggu, prestasi belajar menurun serta dapat mengakibatkan produktivitas kerja yang rendah (2).

Remaja butuh asupan gizi yang optimal untuk pertumbuhan dan perkembangannya. Gizi merupakan suatu proses organisme menggunakan makanan yang dikonsumsi secara normal melalui digesti,absorpsi, transportasi penyimpanan, metabolisme dan pengeluaran zat-zat yang tidak digunakan untuk mempertahankan kehidupan pertumbuhan dan menghasilkan energi (2). Remaja sangat membutuhkan asupan zat besi untuk membentuk sel darah merah. Zat besi diperlukan dalam pembentukan darah dan sintesa hemoglobin. Proses menstruasi mengakibatkan kekurangan zat besi dalam darah, sehingga asupan gizi yang adekuat sangat dibutuhkan pada remaja (2).

Sejak tahun 1996 Kementerian Kesehatan telah mengembangkan program pencegahan dan penanggulangan anemia pada remaja putri dan calon pengantin yang dilakukan secara mandiri di beberapa daerah untuk meningkatkan status kesehatan dan gizi pra hamil sebagai persiapan untuk seorang ibu agar hamil tidak anemia dan melahirkan bayi yang sehat. Program tersebut yaitu berupa suplementasi Tablet Tambah Darah (TTD) seminggu sekali sepanjang tahun, secara menyeluruh (2). Upaya pemerintah untuk mencegah dan meningkatkan cadangan $\mathrm{Fe}$ dalam tubuh, dengan program pemberian TTD. Suplementasi ini mengandung sekurangnya $60 \mathrm{mg}$ elemental besi dan 400 
mcg asam folat. Pemberian suplementasi ini dilakukan di beberapa tatanan seperti fasilitas pelayanan kesehatan, institusi pendidikan, tempat kerja dan KUA/tempat ibadah lainnya (2).

Hasil studi baseline dan riset formatif menemukan di 3 kabupaten/kota di Jawa Barat menemukan 2 dari 3 remaja mengalami anemia. Pengetahuan remaja tentang anemia masih rendah, diantaranya sebagian remaja masih sulit membedakan anemia dan tekanan darah rendah, seluruh remaja memandang TTD hanya sebagai pengobatan dan bukan upaya pencegahan, terdapat persepsi yang salah mengenai efek samping jangka panjang dapat merusak organ dalam. Selain itu ketersediaan materi komunikasi masih kurang (3). Kejadian anemia pada remaja masih tinggi, Anurag (2016) pada penelitiannya menemukan angka kejadian anemia sebesar 69,2\% (4), Abrishami (2017) menemukan sebanyak $87,7 \%$ remaja putri mengalami anemia (5), Deshpande (2016) menemukan 60\% remaja putri mengalami anemia (6). Penelitian Isati (2017) menemukan kejadian anemia pada remaja di Jambi sebesar 87,7\% (7).

Determinan kejadian anemia pada remaja putri meliputi status gizi ((IMT/BMI), Pola makan, konsumsi tablet tambah darah (TTD) dan pengetahuan remaja tentang anemia. Hasil penelitian Kaimudin (2017) di Kendari menemukan status gizi $(\mathrm{p}=0,004)$ berhubungan dengan kejadian anemia pada remaja putri (8). Sharmila (2017) pada penelitiannya dilaporkan bahwa ada hubungan antara IMT dengan kejadian anemia pada remaja putri (9). Deshpande (2013) dalam penelitiannya menemukan remaja putri yang kurus berisiko untuk mengalami anemia (6). Sukarno (2016) menemukan ada hubungan positif antara BMI/IMT dengan kadar hemoglobin pada remaja putri (10).

Hasil penelitian Kaimudin (2017) di Kendari menemukan kebiasaan makan $=0,041$, asupan vitamin $\mathrm{A}=0,048$ Asupan vitamin $\mathrm{C}(\mathrm{p}=0,025)$ berhubungan dengan kejadian anemia pada remaja putri (8). Pauline (2017) pada penelitiannya menemukan ada hubungan antara pola makan dengan kejadian anemia pada remaja putri (9). Azzahroh dalam penelitiannya menemukan ada hubungan antara pengetahuan, motivasi dan dukungan keluarga terhadap kejadian anemia pada remaja (11). Kalsum pada penelitiannya di Jambi (2016) menemukan ada hubungan antara kebiasaan sarapan dengan kejadian anemia (nilai $\mathrm{P}=0,03, \mathrm{OR}=2,05$ ) (12). Nelima (2015) pada penelitiannya di Kenya menemukan ada hubungan antara konsumsi zat besi $(\mathrm{OR}=8,87)$ dengan kejadian anemia pada remaja putri (13). Hasil penelitian Caturiyantiningtyas (2015) di Sukoharjo menemukan ada hubungan antara pengetahuan dengan kejadian anemia pada remaja putri $(\mathrm{p}=0,03)(14)$.

SMP Budi Mulia merupakan salah satu SMP swasta yang berada di wilayah kerja Puskesmas Wadas. Siswi yang bersekolah di SMP tersebut Sebagian besar tinggal di asrama (barak) dalam lingkungan pesantren, mereka berasal dari daerah yang berbeda-beda, yang tentunya memiliki karakteristik yang berbeda juga, sehingga peneliti ingin melakukan penelitian yang terkait dengan anemia di sekolah tersebut. Berdasarkan studi pendahuluan di SMP Budi Mulia, dan informasi dari bidan desa wilayah kerja Puskesmas wadas, ditemukan siswi putri yang yang mengeluh pusing, lemas dan banyak ditemukan siswi putri yang pingsan serta ada keluhan lain yang diduga berkaitan dengan anemia. Menurut informasi dari bidan desa, yaitu 
bidan A, di SMP tersebut pernah dilakukan penyuluhan tentang anemia dan suplementasi TTD, namun belum pernah dilakukan kegiatan evaluasi dampak dari penyuluhan tersebut. Kejadian anemia di SMP tersebut juga belum diketahui, karena belum pernah dilakukan pemeriksaan hemoglobin belum diketahui determinan kejadian anemia pada remaja putri.

\section{METODE}

Desain penelitian menggunakan metode penelitian analitik dengan pendekatan cross sectional, yaitu pengambilan variabel independen dan variabel dependen dikumpulkan dalam waktu yang bersamaan. Variabel independen dalam penelitian ini yaitu status gizi, pola makan, konsumsi Fe dan pengetahuan sedangkan variabel dependen yaitu anemia pada remaja putri. Tempat penelitian ini dilaksanakan di SMP Budi Mulya Karawang, remaja putri tinggal di Pondok Pesantren Wali Barokah. Penelitian dilakukan bulan Januari-Desember 2018. Populasi dalam penelitian ini adalah seluruh siswi SMP Budi Mulia yang berjumlah 230. Cara pengambilan sampel menggunakan rumus estimasi proporsi, didapatkan sebesar 67 responden (15). Data yang dikumpulkan dalam penelitian ini berupa data primer, melalui wawancara, kuesioner, metode recall status gizi gizi Pengukuran kadar hemoglobin menggunakan alat Auto hematologi analyzer yang dilakukan oleh petugas laboratorium Instrumen yang digunakan adalah kuesioner, untuk variabel independen meliputi status gizi, pola makan, pengetahuan, konsumsi fe dan pengetahuan. Timbangan berat badan dan alat tinggi badan untuk mengukur IMT sedangkan yang menjadi variabel dependen adalah anemia pada remaja putri. Variabel independen status gizi berdasarkan pengukuran antropometri (penghitungan
IMT, pengukuran berat badan, tinggi badan) dikelompokan status gizi menjadi $1=$ Kurang, jika $<18,5 ; 2=$ Normal jika 18,5-24,9; $3=$ Gizi lebih jika 25,0-29,9. Pola makan $1=$ Kurang, jika responden menjawab ya $<$ ratarata, 2 = Baik, jika responden menjawab pertanyaan ya $\geq$ rata-rata. Pertanyaan pola makan meliputi frekuensi makan lebih dari 2 kali/hari, kebiasaan sarapan yang dilakukan, macam dan model yang dikonsumsi adalah makanan gizi seimbang terdiri zat tenaga misalnya roti, tepung-tepungan, sumber zat pembangun misalnya ikan, telur, ayam, daging, susu, kacang-kacangan, tahu, tempe, dan sumber zat pengatur seperti sayursayuran, buah-buahan, tidak ada pantangan makanan, tidak melakukan diet langsing, diperoleh dengan metode recall 2x24 jam.Konsumsi Fe 1 = Tidak, jika tidak mengonsumsi TTD $2=$ Ya, jika mengonsumsi TTD. Pengetahuan $1=$ Rendah, jika $<$ rata-rata, $2=$ Tinggi, jika $\geq$ rata-rata, Variabel anemia $1=$ Anemia, jika $\mathrm{Hb}$ kurang dari 12 gr\%, 2 = Tidak anemia, jika $\mathrm{Hb} \geq 12$ gr $\%$.

Instrumen dalam penelitian ini menggunakan instrumen Farida yang telah dilakukan uji validitas dan reliabilitas dan terbukti valid ( $\mathrm{r}$ hitung $>\mathrm{r}$ tabel 0,306 ) dan reliabel (nilai alpha $>0,60$ ). Penelitian ini telah mendapatkan ijin persetujuan etik dari KEP Politeknik Kementerian Kesehatan Bandung nomor: 21/KEPK/PE/V/2018.

\section{HASIL}

Pengambilan data dilakukan pada bulan Juli tahun 2018, dengan jumlah responden penelitian ini sebanyak 67 orang. Adapun hasil penelitian di gambarkan pada tabel di bawah ini:

Kejadian anemia, status Gizi, Pola makan, konsumsi Fe dan Pengetahuan 
Tabel 1. Distribusi frekuensi kejadian anemia, Status gizi, Pola Makan, Konsumsi Fe, Pengetahuan Siswi SMP Budi Mulia Karawang Tahun 2018

\begin{tabular}{lcc}
\hline Faktor determinan & F & $\mathbf{( \% )}$ \\
\hline Anemia & & \\
Anemia & 26 & 38,8 \\
Tidak anemia & 41 & 61,2 \\
Status Gizi & & \\
Kurang & 14 & 20,9 \\
Normal & 47 & 70,1 \\
Lebih & 6 & 9.0 \\
Pola Makan & & \\
Kurang & 33 & 49,3 \\
Baik & 34 & 50,7 \\
Konsumsi Fe & & \\
Tidak & 54 & 80,6 \\
Ya & 13 & 19,4 \\
Pengetahuan & & \\
Rendah & 34 & 50,7 \\
Tinggi & 33 & 49,3 \\
Total & 67 & 100 \\
\hline
\end{tabular}

Hasil penelitian menunjukkan mayoritas remaja putri tidak mengalami anemia sebesar $61,2 \%$, status gizi normal $70,1 \%$, pola makan baik $50,7 \%$, tidak mengonsumsi fe 80,6\%, memiliki pengetahuan rendah sebanyak $50,7 \%$. Berdasarkan tabel 2 ditemukan responden yang mengalami anemia lebih banyak ditemukan pada responden dengan status gizi normal, yaitu $21 \quad(44,7 \%)$, dibandingkan dengan responden dengan status gizi lebih yaitu 2 orang (33,3\%) dan responden dengan status gizi kurang yaitu 3 orang $(21,4 \%)$. Hasil uji menunjukkan tidak ada hubungan yang bermakna antara status gizi dengan anemia dengan nilai $\mathrm{p}=$ $0,281(\mathrm{p}>0,05)$.

Pada faktor pola makan ditemukan responden yang mengalami anemia banyak ditemukan pada responden yang pola makannya kurang yaitu 14 (42,4\%), dibandingkan dengan responden yang pola makannya baik yaitu 12 orang $(35,4 \%)$. Hasil uji chi square menunjukkan nilai $\mathrm{p}$ $=0,728 \quad(p>0,05)$, sehingga disimpulkan tidak ada hubungan yang bermakna antara pola makan dengan anemia pada siswi SMP Budi Mulia. Hasil analisis nilai OR 1,351, artinya responden yang memiliki pola makan kurang baik mempunyai peluang 1,351 kali mengalami anemia dibandingkan dengan responden yang memiliki pola makan baik.

Hubungan Status gizi, pola makanan
konsumsi Fe dan pengetahuan dengan kejadian anemia pada remaja

Tabel 2. Hubungan Status Gizi, Pola Makan, Konsumsi $\mathrm{Fe}$ dan Pengetahuan dengan Anemia Pada Siswi SMP Budi Mulia di Kabupaten Karawang Tahun 2018

\begin{tabular}{|c|c|c|c|c|}
\hline \multirow[b]{2}{*}{ Faktor } & Kejadian & Anemia & \multirow[b]{2}{*}{ Jml } & \multirow{2}{*}{$\begin{array}{c}p \\
\text { value } \\
\text { (OR) }\end{array}$} \\
\hline & Anemia & $\begin{array}{c}\text { Tidak } \\
\text { Anemia }\end{array}$ & & \\
\hline \multicolumn{5}{|c|}{ Status Gizi } \\
\hline Kurang & $\begin{array}{c}3 \\
(21,4 \%)\end{array}$ & $\begin{array}{c}11 \\
(78,6 \%)\end{array}$ & 14 & 0,28 \\
\hline Normal & $\begin{array}{c}21 \\
(44,7)\end{array}$ & $\begin{array}{c}26 \\
(55,3 \%)\end{array}$ & 47 & \\
\hline Lebih & $\begin{array}{c}2 \\
(33,4 \%)\end{array}$ & $\begin{array}{c}4 \\
(66,7 \%)\end{array}$ & 6 & \\
\hline \multicolumn{5}{|c|}{ Pola makan } \\
\hline Kurang & $\begin{array}{c}14 \\
(2,4 \%)\end{array}$ & $\begin{array}{c}19 \\
(57,6 \%)\end{array}$ & 33 & $\begin{array}{c}0,728 / \\
1,351\end{array}$ \\
\hline Baik & $\begin{array}{c}12 \\
(35,3 \%)\end{array}$ & $\begin{array}{c}22 \\
(64 \%)\end{array}$ & 34 & \\
\hline \multicolumn{5}{|c|}{ Konsumsi Fe } \\
\hline Tidak & $\begin{array}{c}22 \\
(40,7 \%)\end{array}$ & $\begin{array}{c}32 \\
(59,3 \%)\end{array}$ & 54 & $\begin{array}{l}0,730 / \\
1,547\end{array}$ \\
\hline Ya & $\begin{array}{c}4 \\
(30,8 \%)\end{array}$ & $\begin{array}{c}9 \\
(69 \%)\end{array}$ & 13 & \\
\hline \multicolumn{5}{|c|}{ Pengetahuan } \\
\hline Rendah & $\begin{array}{c}12 \\
(35,3 \%)\end{array}$ & $\begin{array}{c}22 \\
(6,7 \%)\end{array}$ & 34 & $\begin{array}{c}0,748 / \\
0,740\end{array}$ \\
\hline Tinggi & $\begin{array}{c}14 \\
(42,4 \%)\end{array}$ & $\begin{array}{c}19 \\
(57,6 \%)\end{array}$ & 33 & \\
\hline
\end{tabular}


Pada faktor konsumsi $\mathrm{Fe}$, ditemukan responden yang mengalami anemia banyak ditemukan pada responden yang tidak mengonsumsi fe (TTD) yaitu sebanyak 22 orang $(40,7 \%)$, dibandingkan responden yang mengonsumsi fe yaitu 4 orang (30,8\%). Hasil uji chi square menunjukkan nilai $\mathrm{p}=0,730$ ( $p>0,05)$, sehingga disimpulkan tidak ada hubungan yang bermakna antara konsumsi Fe dengan anemia pada siswi SMP Budi Mulia. Pada hasil analisis ditemukan nilai OR 1,547, artinya responden yang tidak mengonsumsi $\mathrm{Fe}$ mempunyai peluang 1,547 kali mengalami anemia dibandingkan dengan responden yang mengonsumsi $\mathrm{Fe}$.

Faktor pengetahuan, ditemukan responden yang mengalami anemia banyak ditemukan pada responden yang tingkat pengetahuannya tinggi sebanyak 14 orang $(42,4 \%)$ dibandingkan dengan responden yang pengetahuannya rendah yaitu 12 orang $(35,3 \%)$. Hasil uji chi square menunjukkan nilai $p=0,728$ ( $p>0,05)$, sehingga disimpulkan tidak ada hubungan yang bermakna antara pengetahuan dengan anemia pada siswi SMP Budi Mulia. Hasil analisis ditemukan nilai OR 0,740, artinya responden yang memiliki pengetahuan rendah memiliki peluang 0,740 kali mengalami anemia dibandingkan dengan responden yang memiliki pengetahuan tinggi.

\section{PEMBAHASAN}

\section{Kejadian anemia pada siswi SMP Budi Mulia}

Hasil penelitian menunjukkan kejadian anemia pada siswi tahun 2018 di SMP Budi Mulia sebanyak 26 orang (38,8\%), sedangkan yang tidak mengalami anemia sebanyak 41 orang $(61,2 \%)$. Kejadian anemia pada remaja putri di SMP Budi Mulia hal ini mungkin karena siswi remaja yang bersekolah di SMP tersebut salah satunya karena mereka tinggal di pondok atau bisa disebut dengan asrama, dimana kehidupan di asrama menuntut ada keteraturan dalam berbagai hal, diantaranya dalam hal pola makan, jenis dan variasi makanan yang dikonsumsi, dan kualitas gizi dari makanan yang dikonsumsi. Selain itu status ekonomi orang tua siswi remaja tersebut juga dapat dikatakan menengah ke atas, hal tersebut bisa dilihat dari kemampuan para orang tua siswi yang harus memiliki dana lebih untuk menitipkan putrinya bersekolah sekaligus "mondok" tinggal di asrama yang dekat dengan lingkungan sekolah.

Salah satu kondisi kemungkinan penyebab masih adanya kejadian anemia pada remaja putri di SMP tersebut salah satunya disebabkan remaja putri senang mengonsumsi makanan yang diperoleh melalui jajanan di warung atau melalui online di luar lingkungan asrama dimana makanan tersebut kurang mengandung zat besi. Masih ditemukan juga remaja putri yang melewatkan sarapan paginya, dengan alasan sudah terlambat masuk sekolah atau merasa enggan untuk sarapan. Selain itu sebagian remaja putri $(50,7 \%)$ masih kurang pengetahuannya tentang konsumsi $\mathrm{Fe}$, serta manfaat dari mengonsumsi tablet Fe secara teratur. Edukasi, evaluasi dan monitoring dari pihak sekolah sangat penting dilakukan terkait suplementasi tablet Fe, dari apa itu tablet Fe, apa manfaatnya, bagaimana memperolehnya, bagaimana cara mengonsumsinya, zat apa yang bisa menghambat penyerapannya dan lain-lain. Selain itu pihak sekolah bisa bekerja sama dengan pihak puskesmas setempat, untuk melakukan edukasi terkait nutrisi penting pada masa remaja, terutama nutrisi yang banyak mengandung zat besi.

Peran bidan selain di atas juga bisa memberikan motivasi kepada remaja, dimana mereka merupakan calon-calon ibu di masa depan, yang akan mengalami siklus 
reproduksi alamiah, melewati masa kehamilan, melahirkan, nifas, menyusui, dimana kejadian komplikasi yang kemungkinan akan terjadi di masa-masa tersebut dapat dicegah sejak dini, yaitu dengan memastikan remaja tersebut tidak anemia. Remaja yang tidak anemia, diharapkan ketika menjelang dewasa, menikah, hamil, melahirkan, menyusui, juga tidak anemia, dengan tidak anemia maka akan menurunkan risiko terjadi komplikasi, sehingga secara tidak langsung berkontribusi terhadap penurunan angka kesakitan dan angka kematian pada ibu dan bayi. Tujuan asuhan pun tercapai, yaitu ibu dan bayi dalam kondisi aman, sehat dan sejahtera. Anemia merupakan hal yang bisa dicegah, tidak ada kata terlambat untuk mencegahnya, dengan suplai nutrisi yang baik sejak remaja dan dibantu dengan suplementasi tablet $\mathrm{Fe}$ yang teratur, diharapkan remaja putri Indonesia bisa terbebas dari anemia.

Kejadian anemia ini lebih rendah ditemukan dibandingkan dengan kejadian anemia pada remaja pada beberapa tempat, diantaranya yaitu Anurag (2016) pada penelitiannya menemukan angka kejadian anemia pada remaja sebesar 69,2\% (4), Abrishami (2017) menemukan sebanyak $87,7 \%$ remaja putri mengalami anemia (5), Deshpande (2016) menemukan 60\% remaja putri mengalami anemia (6). Penelitian Isati (2017) menemukan kejadian anemia pada remaja di Jambi sebesar 87,7\% (7).

Remaja putri rentan berisiko mengalami anemia, karena proses fisiologis dari menstruasi. Dampak negatif remantri dengan anemia adalah terganggunya pertumbuhan dan perkembangan janin dalam kandungan yang berpotensi timbulnya komplikasi kehamilan dan persalinan, bahkan menyebabkan kematian ibu dan anak (2). Angka kejadian anemia pada responden di SMP Budi Mulia memang belum termasuk prevalensi anemia dengan kategori berat (menurut WHO $>40 \%$ termasuk kategori berat), namun prevalensi ini lebih tinggi dibandingkan dengan anemia pada remaja di negara berkembang (27\%).

Walaupun jumlahnya lebih rendah dibandingkan angka kejadian pada remaja lainnya namun, anemia pada remaja merupakan hal yang berisiko menyebabkan keterlambatan pertumbuhan fisik, gangguan perilaku, dan emosional. Dalam buku Gizi pada Remaja, gangguan tersebut akan mengganggu pertumbuhan dan perkembangan sel otak yang berakibat daya tahan tubuh menurun, mudah lemas, lapar, konsentrasi belajar terganggu, prestasi belajar menurun serta dapat mengakibatkan produktivitas kerja yang rendah (2). Mengingat hal tersebut maka sangat penting melakukan pencegahan kejadian anemia pada remaja khususnya dimulai sejak remaja tersebut menginjak jenjang SMP, agar dampak buruk dari anemia baik jangka pendek dan jangka panjang tidak terjadi. Peran petugas kesehatan tentu sangat penting dalam rangka memberikan edukasi mengenai pencegahan anemia salah satunya dengan pentingnya suplementasi Tablet Fe pada remaja. Anemia pada remaja akan menyebabkan timbulnya masalah kesehatan selanjutnya seperti penyakit tidak menular, produktivitas dan prestasi menurun, termasuk masalah kesuburan. Remaja putri yang menderita anemia berisiko menjadi wanita usia subur yang anemia yang selanjutnya bisa menjadi ibu hamil dengan anemia. Jika saat remaja menderita anemia, ibu hamil berisiko lahirkan anak stunting.

Puskesmas Wadas selaku pendamping dalam bidang kesehatan di wilayah SMP Budi Mulia tentu harus terus melakukan monitoring dan evaluasi 
mengenai berjalannya kegiatan suplementasi TTD tersebut, salah satunya dengan pengecekan berkala pemeriksaan $\mathrm{Hb}$ pada seluruh siswi remaja putri di wilayah puskesmas Wadas, salah satunya di SMP Budi Mulia dengan bekerja sama dengan pihak sekolah, yang mana harapannya angka kejadian anemia pada remaja putri dapat menurun lagi, sehingga kualitas calon-calon ibu akan lebih baik lagi karena terhindar dari anemia.

\section{Status gizi, Pola makan, Konsumsi Fe, Pengetahuan Siswi SMP}

Berdasarkan tabel 1 ditemukan pada status gizi, lebih banyak ditemukan responden yang gizinya normal yaitu 47 orang (70\%), kemudian gizi kurang sebanyak 14 orang $(20,9 \%)$ dan gizi lebih sebanyak 6 orang $(9 \%)$. Status gizi responden rata-rata sudah bagus, dimana ditemukan $70 \%$ responden gizinya normal. Hal ini mungkin karena responden berasal dari keluarga dengan status sosial menengah ke atas, sehingga gizi awalnya sudah baik, ditunjang responden tinggal di pondok (asrama) dimana asupan gizinya lebih baik dengan adanya keteraturan dan monitoring gizi dari asupan makan selama tinggal di pondok. Responden juga bisa memilih jenis makanan yang lebih bervariasi dan bergizi di kantin sekolah.

Pada Pola makan ditemukan responden dengan pola makan baik yaitu 34 orang $(50,7 \%)$, dan pola makan kurang baik yaitu 33 orang $(49,3 \%)$. Pola makan ditemukan dalam keadaan baik 50,7\%, hal ini mungkin karena responden tinggal di pondok, sehingga mendapat keteraturan dalam pola makan, mereka harus bisa mengelola waktu, mana jam sekolah mana jam ke pondok, sehingga hal tersebut berpengaruh dalam hal pola makan yang lebih teratur, dibanding mereka yang tidak tinggal di pondok.
Pada konsumsi Fe (TTD) lebih banyak responden yang tidak mengonsumsi Fe yaitu sebanyak 54 orang $(89,6 \%)$, dan siswi yang mengonsumsi Fe hanya 13 orang $(19,4 \%)$. Responden yang mengonsumsi Fe pada penelitian ini memang hanya ditemukan $19,4 \%$, hal tersebut dilihat bukan hanya pernah mengonsumsi $\mathrm{Fe}$, tapi dilihat keteraturan mereka meminum $\mathrm{Fe}$, karena keteraturan mengonsumsi $\mathrm{Fe}$ cukup berpengaruh terhadap peningkatan $\mathrm{Hb}$ dibandingkan responden yang tidak teratur mengonsumsi $\mathrm{Fe}$ (hanya 1-2 kali mengonsumsi $\mathrm{Fe}$ ). Perlu kerjasama antara tenaga kesehatan, pihak sekolah serta pengelola Pondok untuk memantau keteraturan remaja putri dalam mengonsumsi $\mathrm{Fe}$.

Tingkat pengetahuan responden ditemukan pengetahuan rendah yaitu 34 orang $(50,7 \%)$, sedangkan responden dengan pengetahuan tinggi sebanyak 33 orang (49,3\%). Selisih tingkat pengetahuan responden tidak terlalu banyak, yaitu hanya $1(0,01 \%)$ responden. Pengetahuan remaja lebih rendah ditemukan pada pengetahuan tentang keteraturan konsumsi $\mathrm{Fe}$, atau jadual konsumsi Fe. Remaja putri penting mengetahui bukan hanya aspek anemia pada remaja namun juga cara pencegahan anemia tersebut, salah satunya dengan mengonsumsi TTD secara teratur. Keteraturan tersebut cukup penting dalam rangka meningkatkan kadar hemoglobin darah.

\section{Hubungan Status Gizi dengan anemia pada siswi SMP Budi Mulia}

Berdasarkan tabel 2 ditemukan responden yang mengalami anemia lebih banyak ditemukan pada responden dengan gizi baik, yaitu 21 (44,7\%), dibandingkan dengan responden dengan status gizi lebih yaitu 2 orang $(33,3 \%)$ dan responden dengan status gizi kurang yaitu 3 orang 
$(21,4 \%)$. Beberapa faktor yang memicu terjadinya masalah gizi pada usia remaja seperti kebiasaan makan yang salah, pemahaman gizi yang keliru dimana tubuh yang langsing menjadi idaman para remaja sehingga kebutuhan gizi tidak terpenuhi, dan kesenangan yang berlebihan terhadap makanan tertentu, contohnya makanan cepat saji (fast food). 1

Berdasarkan hasil uji statistik menunjukkan tidak ada hubungan bermakna antara status gizi dengan kejadian anemia ( $\mathrm{p}>0,05)$. Hal ini dikarenakan sebagian besar subyek tergolong dalam status gizi normal. Indikator status gizi adalah IMT/U dipengaruhi asupan zat gizi makro karbohidrat, lemak, protein) (16). Karbohidrat, lemak dan protein merupakan zat gizi penyuplai energi terbesar bagi tubuh (17). Penurunan status gizi dapat terjadi jika dalam jangka waktu tertentu asupan gizi kurang, sebaliknya jika asupan gizi seimbang maka status gizi akan normal, dan bila asupan gizi berlebih maka bisa berpotensi terjadi kegemukan (18). Asupan zat gizi mikro tidak mempengaruhi status gizi berdasarkan IMT/U karena memiliki kandungan energi yang sedikit, dan jika terjadi kekurangan mungkin sudah berlangsung lama(19).

Hasil penelitian ini berbeda dengan hasil penelitian Kaimudin (2017) di Kendari menemukan status gizi $(\mathrm{p}=0,004)$ berhubungan dengan kejadian anemia pada remaja putri (8). Sharmila (2017) pada penelitiannya juga menemukan ada hubungan antara IMT dengan kejadian anemia pada remaja putri (9). Deshpande dalam penelitiannya menemukan remaja putri yang kurus berisiko untuk mengalami anemia (6). Sukarno (2016) menemukan ada hubungan positif antara BMI/IMT dengan kadar hemoglobin pada remaja putri (10).

Jika dilihat dari angka prosentase kejadian anemia, terlihat responden dengan gizi lebih 33,3\% dan gizi kurang 21,4\% jumlahnya $54,7 \%$. Jumlah tersebut lebih besar di banding responden yang mengalami anemia dengan gizi baik yaitu $44,7 \%$. Status gizi yang kurang baik (gizi lebih dan gizi kurang) lebih banyak menyumbang angka kejadian anemia pada remaja $(54,7 \%)$ dibanding dengan remaja yang memiliki gizi baik. Masa remaja merupakan masa yang lebih banyak membutuhkan zat gizi. Remaja membutuhkan asupan gizi yang optimal untuk pertumbuhan dan perkembangannya. Gizi merupakan suatu proses organisme menggunakan makanan yang dikonsumsi secara normal melalui digesti, absorpsi, transportasi penyimpanan, metabolisme dan pengeluaran zat-zat yang tidak digunakan untuk mempertahankan kehidupan pertumbuhan dan menghasilkan energi (4).

Perbedaan hasil penelitian ini dengan beberapa penelitian dan teori, kemungkinan karena status gizi responden penelitian ini sebagian besar sudah baik (44\%), ada faktor lain yang diduga berhubungan dengan anemia, seperti pola menstruasi dan lainlain.

\section{Hubungan Pola Makan dengan anemia pada siswi SMP Budi Mulia}

Berdasarkan tabel 2 ditemukan responden yang mengalami anemia banyak ditemukan pada responden yang pola makannya kurang yaitu 14 (42,4\%), dibandingkan dengan responden yang pola makannya baik yaitu 12 orang $(35,4 \%)$.

Responden penelitian tinggal pada sebuah pondok yang bisa disebut asrama, sebagian responden memiliki pola makan 
yang kurang baik, seharusnya dengan keteraturan tinggal di asrama para remaja tersebut bisa memiliki pola makan yang baik, namun karena sebagian responden mengatakan sering melewatkan sarapan dan ada beberapa yang mengatakan menjaga dengan ketat pola makannya untuk menjaga penampilan agar tidak terlihat gemuk. Walaupun secara statistik tidak ada hubungan antara pola makan dengan kejadian anemia pada remaja, namun remaja yang mengalami anemia ditemukan lebih banyak dengan pola makan kurang baik dibandingkan dengan yang pola makannya baik.

Hasil uji statistik menunjukkan tidak ada hubungan antara pola makan dengan anemia $(p>0,05)$. Pola makan dan asupan zat gizi berpengaruh terhadap kadar $\mathrm{Hb}$. Kekurangan asupan energi dari makronutrien dan mikronutrien dapat berasal dari pola makan, dapat berkontribusi terhadap rendahnya kadar hemoglobin. Energi dibutuhkan dalam proses fisiologi tubuh, jika asupan energi kurang dapat menyebabkan terjadinya pemecahan protein sebagai sumber energi secara terus menerus (20). Anemia pada siswi dikarenakan banyak responden jarang mengonsumsi bahan makanan yang mengandung zat besi, baik dari lauk hewani, protein maupun dari lauk nabati. Asupan zat besi masih di bawah $80 \%$ AKG, dimana rata-rata asupan zat besi hanya $12 \%$ dari AKG (21).

Hasil penelitian ini berbeda dengan hasil penelitian Kaimudin (2017) di Kendari menemukan kebiasaan makan $=0,041$, asupan vitamin $\mathrm{A}=0,048$ Asupan vitamin $\mathrm{C}(\mathrm{p}=0,025)$ berhubungan dengan kejadian anemia pada remaja putri (8). Sharmila (2017) pada penelitiannya menemukan ada hubungan antara pola makan dengan kejadian anemia pada remaja putri (9). Dewi dalam penelitiannya menemukan kebiasaan sarapan berhubungan dengan kejadian anemia pada remaja (22). Suryani (2015) pada penelitiannya di Jambi menemukan ada hubungan antara kebiasaan sarapan dengan kejadian anemia (nilai $\mathrm{P}=0,03, \mathrm{OR}=2,05$ ) (20).

Hasil penelitian ini sama dengan hasil penelitian Suryani (2015) di Bengkulu yang menemukan tidak ada hubungan antara pola makan dengan kejadian anemia pada remaja (20). Status gizi remaja dipengaruhi masa pertumbuhan yang pesat, perubahan psikologis yang dramatis serta peningkatan aktivitas masa remaja, mengakibatkan peningkatan kebutuhan zat gizi, dan terpenuhi atau tidak terpenuhinya kebutuhan, oleh sebab itu asupan makanan pada remaja sebaiknya mengandung jumlah zat-zat gizi yang lebih tinggi daripada sebelumnya.

Pada saat masa growth spurt (masa pacu tumbuh) remaja seringkali makan lebih sering dan jumlah yang banyak. Setelah melewati masa ini remaja akan lebih memperhatikan penampilan diri terutama pada anak remaja putri. Mereka seringkali terlalu ketat dalam pengaturan pola makan guna menjaga penampilannya, sehingga dapat mengakibatkan kekurangan gizi. Peningkatan aktivitas, kehidupan sosial dan kesibukan pada remaja, mempengaruhi kebiasaan makan mereka. Pola konsumsi makanan sering tidak teratur, sering jajan, sering tidak makan pagi (sarapan) dan sama sekali tidak makan siang (2).

Aktivitas yang tinggi baik kegiatan di sekolah maupun di luar sekolah menyebabkan makan menjadi tidak teratur. Makan pagi/sarapan sering terlewatkan, padahal sarapan pada hakekatnya penting untuk menjaga kondisi tubuh dan untuk 
meningkatkan konsentrasi belajar di sekolah. Selain itu tidak jarang mereka makan di luar rumah dengan komposisi gizi yang tidak seimbang.

\section{Hubungan Konsumsi Fe (TTD) dengan anemia pada siswi SMP Budi Mulia}

Berdasarkan tabel 2 ditemukan responden yang mengalami anemia banyak ditemukan pada responden yang tidak mengonsumsi fe (TTD) yaitu sebanyak 22 orang $(40,7 \%)$, dibandingkan responden yang mengonsumsi fe yaitu 4 orang (30,8\%). Hasil uji statistik menunjukan tidak ada hubungan antara konsumsi fe dengan anemia pada remaja putri. Hal ini karena sebagian orang yang mengonsumsi tablet fe tetapi mengalami anemia dikarenakan menderita penyakit kronis seperti kanker dan penyakit ginjal dimana tubuh tidak mampu memproduksi sel darah merah yang cukup, dan dimungkinkan remaja yang mengonsumsi tablet fe bersama dengan zat yang dapat menghambat penyerapan besi seperti teh dan produk-produk kacang kedelai sehingga anemia dapat terjadi.

Hasil penelitian ini berbeda dengan hasil penelitian Nelima Damaris (2015) di Kenya menemukan ada hubungan antara konsumsi zat besi (OR=8,87) dengan kejadian anemia pada remaja putri (13). Namun hasil penelitian ini sama dengan hasil penelitian Lestari di Padang tahun 2017, yang menemukan tidak ada hubungan antara konsumsi Fe dengan kejadian anemia pada remaja (23). Kekurangan Fe dalam makanan sehari-hari dapat menimbulkan kekurangan darah yang dikenal dengan Anemia Gizi Besi (AGB), remaja putri menjadi rawan terhadap AGB karena mengalami menstruasi/haid berkala yang mengeluarkan sejumlah zat besi setiap bulan, oleh sebab itu golongan ini membutuhkan zat besi lebih banyak dari remaja putra. Fe dalam bahan makanan terdapat dalam bentuk besi heme dan besi non heme. Termasuk dalam bahan makanan sumber besi heme adalah daging, ikan unggas. Sedangkan besi non heme antara lain terdapat pada kacang kedelai, kacangkacangan, sayuran berwarna hijau. Ketersediaan hayati/bioavailabilitas besi non heme lebih rendah dari besi heme (2).

Anemia gizi terutama anemia defisiensi besi masih merupakan masalah gizi utama di Indonesia. Beberapa golongan manusia rentan terhadap anemia defisiensi Fe termasuk remaja perempuan. Dampak anemia defisiensi $\mathrm{Fe}$ sangat luas karena berhubungan dengan produktivitas, konsentrasi belajar dan mudah terkena infeksi (2). Pemberian tablet tambah darah kepada remaja dengan pemberian 1x/minggu tablet pada saat menstruasi. Suplementasi ini mengandung sekurangnya $60 \mathrm{mg}$ elemental besi dan $400 \mathrm{mcg}$ asam folat. Pemberian suplementasi ini dilakukan di beberapa tatanan seperti fasilitas pelayanan kesehatan, institusi pendidikan, tempat kerja dan KUA/tempat ibadah lainnya. Sasaran kegiatan suplementasi TTD di institusi sekolah adalah remaja putri usia 12-18 tahun sesuai dengan Surat Edaran Direktorat Jenderal Kesehatan Masyarakat dengan nomor HK 03.03/V/0595/2016. TTD tidak diberikan pada peserta didik perempuan yang menderita penyakit, seperti thalasemia, hemosiderosis atau atas indikasi dokter lainnya (1).

Berbedanya hasil penelitian ini dengan beberapa hasil penelitian dan teori hal ini mungkin karena pola konsumsi yang ditanyakan pada penelitian ini yaitu bukan hanya sekedar pernah atau tidak pernah responden mengonsumsi $\mathrm{Fe}$, namun lebih menekankan ke kualitas konsumsi yaitu teratur atau tidaknya responden meminum 
Fe. Jika dilihat dari hasil wawancara responden sebagian besar pernah mengonsumsi fe namun, hanya di lakukan 1-2 kali, atau jarak konsumsinya terlalu jauh dengan waktu peneliti melakukan pemeriksaan $\mathrm{Hb}$.

Keteraturan remaja dalam mengonsumsi Fe, hal tersebut tentu sangat berperan dalam peningkatan kadar $\mathrm{Hb}$ remaja. Walaupun secara statistik tidak bermakna, namun jika dilihat dari hasil penelitian responden yang tidak teratur mengonsumsi $\mathrm{Fe}$ lebih banyak yang mengalami anemia (40.7\%) dibanding responden yang yang mengonsumsi $\mathrm{Fe}$ secara teratur $(30,8 \%)$. Maka keteraturan dalam mengonsumsi $\mathrm{Fe}$ merupakan hal yang penting dalam upaya pencegahan anemia pada remaja. Hal ini di didukung oleh penelitian Lestari di Padang tahun 2017, yang menemukan adanya pola yang positif yaitu semakin tinggi konsumsi fe maka semakin tinggi kadar Hbnya.

\section{Hubungan Pengetahuan dengan anemia pada siswi SMP Budi Mulia}

Hasil penelitian menunjukkan tidak ada hubungan yang bermakna antara pengetahuan dengan kejadian anemia dengan nilai $\mathrm{p}=0,728(\mathrm{p}>0,05)$. Hal ini dimungkinkan karena pengetahuan bukan merupakan faktor utama terjadinya anemia pada remaja putri, faktor lain dapat menyebabkan terjadinya anemia yaitu karena penyakit atau infeksi kronis dapat menyebabkan tubuh memproduksi lebih sedikit sel darah merah. Hal ini dapat menyebabkan penurunan hemoglobin dan menyebabkan anemia, terlalu banyak sel darah merah adalah penyebab umum anemia. Pada remaja, menstruasi berat terkadang bisa membuatnya mengalami anemia.kehilangan darah saat menstruasi, jumlah makanan atau diet yang buruk dari zat besi, vitamin B12, vitamin B6, vitamin $\mathrm{C}$ dan tembaga.

Hasil penelitian ini berbeda dengan hasil penelitian Caturiyantiningtyas (2015) di Sukoharjo menemukan ada hubungan antara pengetahuan dengan kejadian anemia pada remaja putri $(\mathrm{p}=0,03)(14)$. Namun hasil penelitian ini sama dengan hasil penelitian Suryani di Bengkulu tahun 2015 yang menemukan tidak ada hubungan antara pengetahuan dengan kejadian anemia pada remaja (20). Pengetahuan dapat diperoleh melalui pendidikan formal, nonformal, media massa dan orang lain. Orang yang memiliki pengetahuan yang baik akan memiliki kecenderungan untuk bersikap baik yang selanjutnya akan mempengaruhi perilaku. Pengetahuan seseorang akan berpengaruh terhadap sikap dan perilaku dalam pemilihan makanan dan selanjutnya akan berpengaruh terhadap keadaan gizi individu yang bersangkutan termasuk status anemia $(22,24,25)$.

Pada hasil penelitian ini ditemukan pengetahuan remaja paling banyak dengan pengetahuan rendah $(50,7 \%)$. Rendahnya pengetahuan remaja tentang anemia mengakibatkan kurangnya konsumsi sumber protein hewani. Tidak adanya hubungan antara pengetahuan dengan anemia, hal ini dimungkinkan pengetahuan yang tinggi tidak menjamin dapat mempengaruhi perilaku seseorang dalam pemilihan makanan sehari-hari. Pengetahuan yang dimiliki remaja belum diterapkan dalam kehidupan sehari-hari. Contohnya mereka tahu tentang pentingnya konsumsi $\mathrm{Fe}$ secara benar dan teratur namun mereka tidak mengonsumsi fe dengan benar dan dan teratur. Hal ini menggambarkan bahwa pengetahuan yang tinggi belum dapat merubah perilaku yang positif. 


\section{SIMPULAN}

Kejadian anemia pada remaja putri di SMP Budi Mulia Kabupaten Karawang tahun 2018 yaitu sebesar 38,8\%. Determinan yang ditemukan presentasenya paling banyak yaitu: status gizi normal Pola makan baik, tidak mengonsumsi Fe, dan pengetahuan rendah. Kejadian anemia pada remaja putri banyak ditemukan pada responden yang memiliki pola makan kurang serta tidak mengonsumsi Fe. Tidak ditemukan hubungan antara kejadian anemia pada remaja putri dengan determinan: status gizi, pola makan, konsumsi Fe, dan pengetahuan.

\section{UCAPAN TERIMA KASIH}

Ucapan terima kasih penulis sampaikan kepada pihak Direktorat Poltekkes Kemenkes Bandung, bagian SUPM, komite kaji etik dan pengelola Program Studi Kebidanan Karawang.

\section{KONFLIK KEPENTINGAN}

Kami sebagai tim peneliti menyatakan penelitian ini tidak mengandung unsur konflik kepentingan, dan tidak ada afiliasi atau koneksi dengan organisasi apa pun.

\section{REFERENSI}

1. Kemenkes Republik Indonesia.

Pedoman Pencegahan dan

Penanggulangan Anemia Pada

Remaja Putri dan Wanita Usia Subur (WUS). Direktorat Gizi Masyarakat Direktorat Jenderal Kesehatan Masyarakat RI; 2016.

2. Savitri S. Gizi Remaja Putri. Jakarta: FKUI; 2006.

3. Karyadi Elvina. Studi Baseline dan Riset Formatif Program Suplementasi Tablet Tambah Darah bagi Remaja Putri di 3 Kabupaten/Kota di Provinsi Jawa
Barat. 2017.

4. Srivastava A, Kumar R, Sharma M. Nutritional anaemia in adolescent girls: an epidemiological study. Int J Community Med Public Heal [Internet]. 2016;3(4):808-12. Available from: http://ijcmph.com/index.php/ijcmph /article/view/801

5. Abrishami F, Golshan A. Frequency of Iron Deficeincy Anemia in Girls Studying in Mashad High Schools. Iran J Ped Hematol Oncol. 2013;3(4):143-8.

6. Deshpande N, Karva D, Agarkhedkar S, Deshpande S. Prevalence of anemia in adolescent girls and its co-relation with demographic factors. Int $\mathrm{J}$ Med Public Heal [Internet]. 2013;3(4):235. Available from: http://ijmedph.org/article/87

7. Isati, Hastono SP. Determinan Kejadian Anemia Remaja Putri di SMP Negeri 22 Kota Jambi. J Kesmas Jambi [Internet]. 2017 May 19;1(1):1-10. Available from: https://online-

journal.unja.ac.id/jkmj/article/view/ 3685

8. La Kaimudin N, Lestari H, Afa JR. Skrining dan Determina kejadian Anemia pada Remaja Putri SMA Negeri 3 Kendari Tahun 2017. J Ilm Mhs Kesehat Masy. 2017;2(6):1-10.

9. Sharmila P, Kumar RSR. Correlation between Prevalance of Anemia and Body Mass Index among Adolescent Girls. Int J Sci Res. 2017;6(11):3203.

10. Sukarno J, Marunduh R, Pangemanan DHC, Fakultas S, Universitas K, Ratulangi S, et al. Hubungan Indeks Massa Tubuh 
Dengan Kadar Hemoglobin Pada

Remaja Di Kecamatan Bolangitang

Barat Kabupaten Bolaang

Mongondow Utara. JKK (Jurnal Kedokt Klin. 2016;1(1):29-35.

11. Azzahroh P, Rozalia F. Faktor-

Faktor yang Berhubungan dengan

Kejaidan Anemia pada Remaja Putri di SMAN 2 Kota Jambi. J Ilmu dan Budaya. 2018;41(58):6797-816.

12. Kalsum U, Halim R. Kebiasaan Sarapan Pagi Berhubungan Dengan Kejadian Anemia Pada Remaja. J Penelit Univ Jambi Seri Sains. 2016;18(1):09-19.

13. Nelima Damaris. Prevalence and Determinants of Anaemia among Adolescent Girls in Secondary Schools in Yala Division Siaya District, Kenya. Horiz Res Publ Corp. 2015;3 (1).

14. Caturiyantiningtiyas T. Hubungan Antara Pengetahuan, Sikap dan Perilaku dengan Kejadian Anemia Remaja Putri Kelas X dan XI SMA Negeri 1 Polokarto. Universitas Muhammadiyah Surakarta; 2015.

15. Soekidjo N. Metodelogi Penelitian eksehatan. Rineka Cipta; 2010.

16. Sari RI, Dewi Sartika RA. Factors Associated with Nutritional Status of Adolescents Age 12-15 Years in Indonesia (Secondary Data Analysis of RISKESDAS 2007). KnE Life Sci. 2019;4(10):359.

17. Arisman. Gizi dalam Daur Kehidupan. Jakarta: Buku Kedokteran, EGC; 2009.

18. Moehji. Penanggulangan Gizi
Buruk. Jakarta: Papar Sinar Sinanti; 2003.

19. Rosmalina Y, Ernawati F. Hubungan Status Zat Gizi Mikro dengan Status Gizi Pada Anak Remaja SLTP. Hub Status Gizi Mikro. 2010;33(1):1422.

20. Suryani D, Hafiani R, Junita R. Analisis Pola Makan dan Anemia Gizi Besi pada Remaja Putri Kota Bengkulu. J Kesehat Masy Andalas. 2015;10(1):11-8.

21. Lewa AF. Hubungan Asupan Protein , Zat Besi Dan Vitamin C Dengan Kejadian Anemia Pada Remaja Putri Di MAN 2 Model Palu. Publ Kesehat Masy Indones [Internet]. 2016;3(1):26-31. Available from: http://ejournal-

s1.undip.ac.id/index.php/jkm

22. Wawan A, Dewi M. Teori \& Pengukuran Pengetahuan, Sikap, dan perilaku manusia. Yogyakarta: Nuha Medika; 2014.

23. Lestari IP, Lipoeto NI, Almurdi A. Hubungan Konsumsi Zat Besi dengan Kejadian Anemia pada Murid SMP Negeri 27 Padang. J Kesehat Andalas [Internet]. 2018 Feb 20;6(3):507. Available from: http://jurnal.fk.unand.ac.id/index.ph $\mathrm{p} / \mathrm{jka} /$ article/view/730

24. Departemen Gizi dan Kesehatan Masyarakat. Gizi dan Kesehatan Masyarakat. Jakarta: Kementerian Kesehatan Republik Indonesia; 2011.

25. Soekidjo N. Ilmu Perilaku Kesehatan. Rineka Cipta; 2010. 